\title{
Asthma Exacerbations in a Tertiary Hospital: Clinical Features, Triggers, and Risk Factors for Hospitalization
}

\author{
Pola-Bibian B ${ }^{1}$, Dominguez-Ortega J1,4, Vilà-Nadal G' ${ }^{1}$ Entrala A', González- \\ Cavero $\mathrm{L}^{1}$, Barranco $\mathrm{P}^{1,4}$, Cancelliere $\mathrm{N}^{2}$, Díaz-Almirón $\mathrm{M}^{3}$, Quirce $\mathrm{S}^{1,4}$
}

\author{
'Department of Allergy, Hospital La Paz Institute for Health Research (IdiPAZ), Madrid, Spain \\ ${ }^{2}$ Department of Emergency Medicine, Hospital Universitario La Paz, Madrid, Spain \\ ${ }^{3}$ Department of Biostatistics, Hospital Universitario La Paz, Madrid, Spain \\ ${ }^{4} \mathrm{CIBER}$ de Enfermedades Respiratorias, CIBERES, Madrid, Spain
}

J Investig Allergol Clin Immunol 2017; Vol. 27(4): 238-245

doi: $10.18176 /$ jiaci.0128

\begin{abstract}
Background: The risk factors for asthma exacerbations are not fully understood. The aim of this study was to determine the epidemiological and clinical characteristics of patients who experience asthma exacerbations. We also assessed potential triggers of exacerbations and possible predictors of hospitalization.

Methods: A retrospective, noninterventional cohort study was conducted in adult patients who attended the emergency department of a tertiary hospital with an asthma exacerbation during 2014.

Results: The study population comprised 831 patients (888 events). Most episodes occurred in January and May. Respiratory infection was the trigger in 523 events. In $34.21 \%$ of cases, the eosinophil count was $\geq 260 / \mathrm{mm}^{3}\left(\geq 400 / \mathrm{mm}^{3}\right.$ in $20.7 \%$ ), which was significantly associated with allergic asthma $(P<.0001)$. The risk factors for hospitalization were older age $(\mathrm{OR}, 1.58 ; 95 \% \mathrm{Cl}, 1.46-1.71)$, no previous diagnosis of asthma (OR, 1.40; $95 \% \mathrm{Cl}, 1.06-1.86)$, poorly controlled asthma $(\mathrm{OR}, 1.78 ; 95 \% \mathrm{Cl}, 1.10-2.88)$, respiratory infection (OR, $2.65 ; 95 \% \mathrm{Cl}, 1.95-3.62)$, and severe exacerbation with more treatment requirements. The rate of hospitalization was significantly lower in patients with $\geq 400$ eosinophils $/ \mathrm{mm}^{3}(P<.001)$.

Conclusion: Older age, absence of a previous asthma diagnosis, uncontrolled disease, and concomitant chronic obstructive pulmonary disease are frequent among patients presenting at the emergency department with asthma exacerbations. Various features were associated with a higher risk of admission. Blood eosinophilia should be considered a marker of asthma, but not a predictor of hospitalization.
\end{abstract}

Key words: Asthma. Exacerbation. Risk of hospital admission. Eosinophilia.

\section{Resumen}

Introducción: Los factores de riesgo de las exacerbaciones de asma no se conocen por completo. El objetivo de este estudio fue determinar las características epidemiológicas y clínicas de los pacientes con exacerbaciones de asma, los potenciales factores desencadenantes y los posibles predictores de hospitalización.

Métodos: Se llevó a cabo un estudio de cohorte retrospectivo, no intervencionista, en pacientes adultos que acudieron al Servicio de Urgencias de un hospital terciario con una exacerbación de asma durante el año 2014.

Resultados: Se incluyeron 831 pacientes (888 eventos). El mayor número de episodios ocurrió en Enero y Mayo. La infección respiratoria se consideró como desencadenante en 523 eventos. 34,21\% tenían $\geq 260$ eosinófilos $/ \mathrm{mm}^{3}$ ( $20,7 \% \geq 400$ eosinófilos $\left./ \mathrm{mm}^{3}\right)$, estando lo cual asociado significativamente con el asma alérgica ( $<<0,0001)$. Los factores de riesgo para la hospitalización fueron: edad avanzada [OR: 1,58 (IC 95\%: 1,46 a 1,71)]; ausencia de diagnóstico previo de asma [OR: 1,40 (IC 95\%: 1,06-1,86)]; mal control del asma [OR: 1,78 (IC 95\%: 1, 10-2,88)]; infección respiratoria [OR: 2,65 (IC 95\%: 1,95-3,62)]; y crisis graves con mayor necesidad de tratamiento. En los asmáticos con $\geq 400$ eosinófilos $/ \mathrm{mm}^{3}$, la tasa de hospitalización fue menor $(p<0,001)$.

Conclusión: La edad avanzada, la ausencia de un diagnóstico de asma previo, el mal control de la enfermedad o el padecer EPOC de forma concomitante son frecuentes entre los pacientes que acuden al Servicio de Urgencias con exacerbaciones de asma. Se detectaron algunas características asociadas con un mayor riesgo de ingreso. La eosinofilia periférica debe ser considerada como un marcador de asma, pero no como un predictor de la hospitalización.

Palabras clave: Asma. Exacerbación. Riesgo de hospitalización. Eosinofilia. 


\section{Introduction}

Most patients with asthma remain symptomatic despite maintenance treatment and experience exacerbations, which are indicative of poor asthma control [1]. An asthma exacerbation is defined as worsening of asthma symptoms and lung function that requires an increase in medication (including systemic corticosteroid therapy), a visit to the emergency department, or hospitalization [2]. Although some countries have seen a decline in asthma-related hospitalizations and deaths [3], the global burden of exacerbations and day-to-day symptoms has increased by almost $30 \%$ in the past 20 years [4]. In fact, exacerbations are the main cause of morbidity and mortality in patients with asthma [5], thus increasing the annual cost of treatment 3-fold [6]. Patients who have frequent exacerbations usually experience an accelerated loss of lung function [7].

Asthma exacerbations are commonly triggered by upper respiratory tract infections and/or exposure to environmental allergens and, less frequently, by other factors [8]. The specific features and conditions associated with an increased risk of exacerbations in adults include obesity, smoking, severe sinus conditions, allergy, gastroesophageal reflux (GER), repeated respiratory infections, psychiatric disorders, obstructive sleep apnea syndrome, vitamin D deficiency, nonwhite race, low socioeconomic status, and female sex [9]. Indicators of poor asthma control (eg, an exacerbation in the previous year or $\geq 3$ cycles of oral corticosteroids, poor treatment adherence [10], and eosinophilia in sputum [11] or blood [12]) are considered risk factors for exacerbation.

Knowing which risk factors could lead to an exacerbation, recognizing indicators of potential severity, and establishing the most appropriate treatment and more effective preventive measures are not only necessary, but could prove indispensable for improving control of asthma. The profile of asthma exacerbations in Spain has been assessed. In 2009, the results of a study of 262 episodes of asthma exacerbation treated in a hospital emergency department (ED) and home care services in Barcelona [13] revealed that the most frequent etiology was possible viral infection of the respiratory tract, although the observation period was limited to October and November. Retrospective studies have been published on quality of care [14] and epidemiology [15]. Many relevant issues associated with exacerbations remain unresolved, and more information could help to prevent onset.

The present study was designed to assess the epidemiological and clinical characteristics, potential triggering factors, and possible predictors of hospitalization in patients (with or without a prior diagnosis of asthma) who had experienced at least 1 asthma exacerbation and were treated in the ED of a tertiary hospital in Spain.

\section{Methods}

We conducted a retrospective and observational (noninterventional) cohort study using data collected from medical records and charts at the ED of La Paz University Hospital, Madrid, Spain. This hospital is the tertiary referral center for a population of 500000 in northern Madrid. The total number of ED visits was 211031 in 2014 [16]. The study was approved by the local ethics committee, and permission was obtained from the hospital for the use of confidential data.

A specific search was performed following any of the International Statistical Classification of Diseases and Related Health Problems 9th Revision (ICD-9-CM) codes for asthma (493; 493.0; 493.1; 493.2; 493.8; and 493.9) [17], and a supplementary search was later performed following other possible and noncoded diagnoses, namely, bronchial asthma, asthmatic bronchitis, asthmatic crisis, acute asthma attack, and asthma exacerbation. Events in which chronic obstructive pulmonary disease (COPD) or COPD exacerbation was mentioned as a possible cause for the ED visit were excluded. An isolated diagnosis of pneumonia was also excluded. All patients aged $>14$ years who attended the ED with one of the aforementioned "labels" suggestive of an asthma exacerbation from January 1 to December 31, 2014 were enrolled. Data were collected by the same 4 investigators during the inclusion period. Each episode was defined as an event. After discharge from the ED or hospital and a period of 7 days of stability after resolution of an exacerbation $[18,19]$, cases in which the same patient visited the ED less than 15 days after the previous event were classified as relapses, while visits after this 15 -day period were considered new events.

For each event, 84 variables were identified for data collection and grouped under the following 5 headings: (1) patient characteristics, namely, epidemiology and comorbid conditions (including asthma diagnosis and previous level of control according to then current consensus criteria of the 2009 Spanish guideline on asthma management [GEMA]) [21], and regular treatments; (2) evaluation of the asthma exacerbation (trigger factors if they were explicitly recorded in the chart [ICD-9-CM codes 465 and 466 for respiratory infections, 477 for allergic rhinitis, 372 or 995 for allergy, and 935.8 for nonsteroidal anti-inflammatory drugs]) [17], clinical features, such as cough, wheezing, and fever), and severity of the exacerbation (defined by GEMA 2009) [20], laboratory tests (especially eosinophil count, with eosinophilia defined as $\geq 260 / \mathrm{mm}^{3}$ in blood) [21]; (3) treatment administered at the ED; (4) patients' response to treatment, and subsequent outcome (discharge, observation, hospital admission, intensive care admission, or death); and (5) referral to an asthma specialist (allergist or pulmonologist) at discharge. As elevated blood eosinophil counts have been proposed as a risk factor for asthma exacerbations, we also considered a cutoff of $400 / \mathrm{mm}^{3}$, as previously reported [12].

\section{Statistical Analysis}

Quantitative data are expressed as mean (SD), maximum, and minimum. Discrete variables are presented as a frequency distribution, percentages, and, when necessary, 95\% confidence intervals. The Pearson chi-square test or Fisher's exact test were used as appropriate for a univariate exploratory analysis of discrete variables. Correlated data were analyzed using a generalized linear mixed model (GLMM) with the restricted maximum pseudolikelihood method. With respect to the first objective, the "probability of the event" (for each event separately: asthma event, admission, and relapse), a random intercept, and an unstructured covariance matrix were added to the GLMM with a binomial distribution and logit link 
function to test the need for a random effect. If a random effect was not necessary, logistic regression was used to estimate the probability of the event. Specific epidemiological and clinical variables were then added into the model, and their relationships with the binary outcome were estimated and expressed as the odds ratio (OR). The Mann-Whitney test was used to assess the role of eosinophil level $\left(<260 / \mathrm{mm}^{3}\right)$ and patient age. The relationship between age and the month of the event was estimated using Spearman correlations. All tests were 2-tailed, and significance was set at $P<.05$. An exploratory univariate analysis was performed using IBM SPSS Statistics for Windows, Version 20.0 (IBM Corp), while GLMM analysis was carried out using SAS Enterprise Guide 5.1 (SAS Institute Inc). The procedures used were "proc glimmix" and "proc logistic".

\section{Results}

The study population comprised 831 patients (563 women), who experienced 888 episodes; 54 patients had $>1$ episode. Mean age was 57.3 years (range, 14-102 years). Data on patient characteristics and comorbidities are shown in Table 1. When information on variables such as obesity, GER, or confirmed nasal polyps could not be collected from a sufficient number of patients, it was not included in the final analysis. The average likelihood of relapse was $6 \%$ and that of hospitalization $32 \%$ (Table 2).

In this population, $45.7 \%$ of patients $(n=380)$ had no previous recorded diagnosis of asthma. Among those already diagnosed with asthma $(n=451), 81$ were not receiving regular treatment, 108 (23.94\%) used only a short-acting $\beta$-agonist (SABA) as needed, and 255 (more than half of the known asthmatic population) were on regular treatment with inhaled corticosteroids with or without long-acting $\beta$-agonists. A total of 102 patients (12.27\%) had experienced at least 1 exacerbation requiring emergency care in the previous year. Only 15 patients had ever been admitted to the intensive care unit.

A blood eosinophil count was obtained from 681 patients. Overall, 233 patients (34.21\% of those tested) had an eosinophil count $\geq 260 / \mathrm{mm}^{3}$, whereas 141 (20.7\% of the tested population) had $>400 / \mathrm{mm}^{3}$. Eosinophilia was weakly associated with younger age and weakly but significantly associated with a diagnosis of respiratory allergy $(P<.0001)$. The OR for this association increased by $1.16(95 \% \mathrm{CI}, 1.1-$ 1.22) for every additional 100 cells $/ \mathrm{mm}^{3}$.

The distribution of the total 888 events per month is shown in Figure 1. The frequency of episodes was highest in January and May (142 [16\%] and 158 [17.8\%], respectively) and lowest in July and August. However, April and November were the months with the highest rates of hospitalization (43.4\% and 38.3\%, respectively). The suspected etiologies of the exacerbations and their clinical characteristics are reported in Table 3. Respiratory infection was the most common trigger for exacerbation (523 episodes [58.9\%]), followed by direct exposure to aeroallergens (in 70 episodes [7.9\%]). The triggering agents or factors were not identified in $29 \%$ of episodes.

As for severity, 319 of the 888 exacerbations (35\%) were considered moderate-to-severe, with a risk of imminent respiratory arrest in 5 cases. The most common symptoms were dyspnea $(90 \%)$ and cough $(78 \%)$, mostly without expectoration (54\%). Ten patients arrived with an altered level

Table 1. Demographic and Clinical Features of the Study Population $(\mathrm{N}=831)$

\begin{tabular}{lc}
\hline & No. $(\%)$ \\
\hline Gender & 563 female (67.7)/ \\
& 268 male (32.3) \\
\hline Smokers & $150(18.1)$ \\
Ex-smokers & $102(12.3)$ \\
Previous diagnosis of asthma & $451(54.3)$ \\
Previous diagnosis of respiratory allergy & $117(14.1)$ \\
Previous diagnosis of COPD & $114(13.7)$ \\
Previous diagnosis of psychiatric disorders & $166(20)$ \\
Previous diagnosis of drug allergies & $135(16.2)$ \\
Previous diagnosis of high blood pressure & $296(35.6)$ \\
Previous diagnosis of diabetes mellitus & $116(14)$ \\
Previous diagnosis of dyslipidemia & $131(15.8)$ \\
Regular treatment with statins & $150(18)$ \\
Regular treatment with ACE inhibitors & $138(16.6)$ \\
Regular treatment with ß-blockers & $72(8.7)$ \\
Regular treatment with NSAIDs & $27(3.3)$ \\
\hline
\end{tabular}

Abbreviations: ACE, angiotensin-converting enzyme; $C O P D$, chronic obstructive pulmonary disease; NSAID, nonsteroidal anti-inflammatory drug.

Table 2. Average Probability of Hospitalization, More Than One Event, and Relapse in The Study Population Estimated Using A Generalized Linear Mixed Model

\begin{tabular}{lccccc}
\hline Effect & Estimate & $\begin{array}{c}\text { Standard } \\
\text { Error }\end{array}$ & $P$ Value & Mean & $\begin{array}{c}\text { Standard } \\
\text { Error of } \\
\text { Mean }\end{array}$ \\
\hline Admission & -0.7496 & 0.0721 & $<.0001$ & 0.3209 & 0.01569 \\
$\geq 1$ event & -0.0420 & 0.1052 & $<.0001$ & 0.1149 & 0.01070 \\
Relapse & -2.7372 & 0.1404 & $<.0001$ & 0.06081 & 0.008020 \\
\hline
\end{tabular}

Number of Episodes

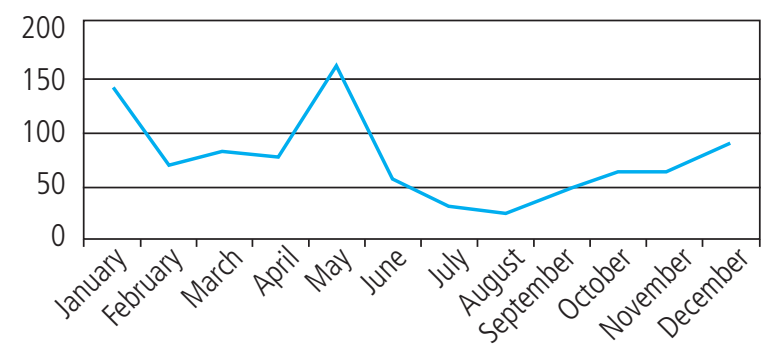

Figure 1. Monthly Distribution of Exacerbations. 
Table 3. Clinical Characteristics of the Exacerbations ( $N=888)$

\begin{tabular}{|c|c|}
\hline Severity & $\%$ \\
\hline Mild & 60 \\
\hline Moderate-to-severe & 35 \\
\hline Imminent respiratory arrest & 0.5 \\
\hline \multicolumn{2}{|l|}{ Suspected triggers } \\
\hline Respiratory infection & 59 \\
\hline Respiratory allergy & 8 \\
\hline Physical exercise & 0.8 \\
\hline Drug intake & 0.6 \\
\hline Psychological factors & 0.6 \\
\hline Food allergy & 0.1 \\
\hline Others and unknown & 28 \\
\hline \multicolumn{2}{|l|}{ Symptoms } \\
\hline Dyspnea & 90.5 \\
\hline Cough & 78 \\
\hline Expectoration & 46 \\
\hline Wheezing & 43 \\
\hline Low level of consciousness & 1.1 \\
\hline Chest tightness & 15 \\
\hline Nasal symptoms & 13 \\
\hline Ocular symptoms & 4 \\
\hline \multicolumn{2}{|l|}{ Physical examination } \\
\hline Auscultation: normal & 19.5 \\
\hline Auscultation: wheezing & 78 \\
\hline Auscultation: abolished sounds & 2.5 \\
\hline Tachycardia $>99$ bpm & 33.5 \\
\hline Tachypnea $>19$ rpm & 26.8 \\
\hline High temperature $\left(>37.7^{\circ} \mathrm{C}\right)$ & 3.6 \\
\hline Basal oxygen saturation $<92 \%$ & 31 \\
\hline
\end{tabular}

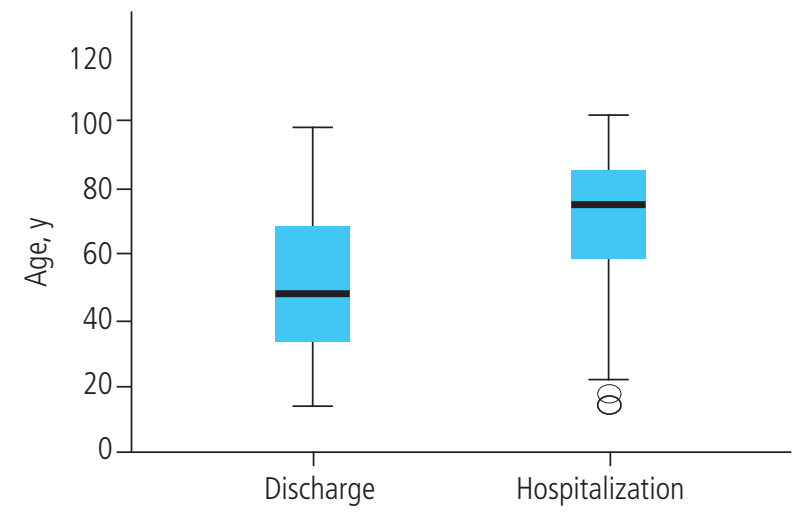

Figure 2. Association Between Age and Hospitalization. of consciousness. Physical examination revealed wheezing in $77 \%$ of cases and absent breath sounds in only 25 patients. Baseline oxygen saturation $<92 \%$ was observed in $31 \%$ of patients. Overall, $51 \%$ of the episodes required systemic corticosteroids, and $25 \%$ were treated with antibiotics. After treatment, approximately $68 \%$ of patients were discharged (8.3\% after staying in an observation bay), and 259 patients (285 events [32.1\%]) were admitted (6 to the intensive care unit). No fatal events due to asthma attacks were registered.

Associations between the variables of interest and hospitalization are shown in Table 4. In general, the variables associated with a higher risk of admission were older age (Figure 2), absence of a previous diagnosis of asthma or uncontrolled disease, suspected respiratory infection, severe crisis, and increased need for ED treatment. However, only $25.5 \%$ of patients with a blood eosinophil count $>400 / \mathrm{mm}^{3}$ required hospitalization, compared with $44.2 \%$ of those with $<400 / \mathrm{mm}^{3}(P<.001)$.

Table 4. Relationship Between Hospitalization and the Outcomes Analyzed

\begin{tabular}{|c|c|c|}
\hline & OR & $95 \% \mathrm{CI}$ \\
\hline Older age & 1.58 & $1.46-1.71$ \\
\hline Male gender & 0.981 & $0.724-1.328$ \\
\hline No previous diagnosis of asthma & 1.403 & $1.056-1.863$ \\
\hline Uncontrolled asthma & 1.786 & $1.105-2.879$ \\
\hline $\begin{array}{l}\text { Mild exacerbation } \\
\text { (vs moderate/severe) }\end{array}$ & 0.091 & $0.065-0.128$ \\
\hline Ex-smokers vs smokers & 1.746 & $1.073-2.843$ \\
\hline $\begin{array}{l}\text { Previous diagnosis of } \\
\text { diabetes mellitus }\end{array}$ & 3.247 & $2.205-4.781$ \\
\hline Previous diagnosis of dyslipidemia & 2.020 & $1.401-2.912$ \\
\hline $\begin{array}{l}\text { Previous diagnosis of } \\
\text { respiratory allergy }\end{array}$ & 0.324 & 0.194-0.539 \\
\hline Previous diagnosis of drug allergies & 2.130 & $1.489-3.048$ \\
\hline $\begin{array}{l}\text { Previous diagnosis of high } \\
\text { blood pressure }\end{array}$ & 3.778 & $2.805-5.089$ \\
\hline Respiratory infection as a trigger & 2.655 & $1.948-3.618$ \\
\hline Respiratory allergy as a trigger & 0.159 & $0.068-0.369$ \\
\hline Blood eosinophilia $\left(>260 / \mathrm{mm}^{3}\right)$ & 0.459 & $0.327-0.644$ \\
\hline $\begin{array}{l}\text { Arterial blood gases in the } \\
\text { emergency department }\end{array}$ & 8.314 & $5.783-11.954$ \\
\hline Treatment with oxygen & 7.082 & $5.142-9.753$ \\
\hline $\begin{array}{l}\text { Treatment with short acting inhaled } \\
\beta_{2} \text {-agonists }\end{array}$ & 1.825 & $1.290-2.581$ \\
\hline Treatment with corticosteroids & 2.374 & $1.741-3.238$ \\
\hline $\begin{array}{l}\text { Treatment with inhaled } \\
\text { ipratropium bromide }\end{array}$ & 1.935 & $1.372-2.729$ \\
\hline Treatment with antibiotics & 10.379 & $7.286-14.787$ \\
\hline
\end{tabular}




\section{Discussion}

The incidence of asthma exacerbations according to reallife surveys is much higher than in clinical trial settings [4]. Moreover, exacerbations affect patients with poorly controlled asthma irrespective of severity, even in those treated with inhaled corticosteroids [23]. Loss of asthma control usually leads to unscheduled clinical visits; in one study, $70 \%$ of uncontrolled asthmatics had an unscheduled visit to a physician, $36 \%$ had an ED visit, and 14\% had been hospitalized in the previous year [24]. Indeed, experiencing an asthma exacerbation in the previous year is the strongest predictor of future exacerbations in adults [25]. In the population we studied, a large number of asthmatics were receiving SABA monotherapy. Despite the major role of inflammation in asthma and even 15 years after the AIRE study, in which more patients had used rescue medication $(63 \%)$ than inhaled corticosteroids (23\%) in the previous 4 weeks [26], we still find that many patients diagnosed with asthma are not on regular maintenance treatment. This might be a consequence of an overestimation of asthma control that does not match symptom severity. However, the number of patients who had visited the ED during the preceding year was lower in our sample than in other published observational studies [23], and, interestingly, did not significantly predict a new exacerbation during the period analyzed.

A potential limitation of the present study was the lack of data for all the outcomes, which was a consequence of the retrospective design. Therefore, a prospective cohort is warranted to assess the actual influence of previous exacerbation. One of the major strengths, however, is the inclusion of patients seen in the same hospital by the same ED medical team throughout the year, which decreases the risk of bias, even as a result of seasonal patterns. Our sample is representative of real-life practice in our geographic area and indicates that a substantial number of asthmatic patients might not be correctly diagnosed and may be receiving substandard care or even going untreated. It is remarkable that $45 \%$ of the patients who experienced an asthma exacerbation in this study had no previous diagnosis of asthma or that this disease had not been adequately entered into the medical record in the ED. We believe that the retrospective character of the study may have influenced data collection, especially since we only considered data recorded in the charts, as is the case in real-world practice, and therefore tried to avoid any interpretation bias by the investigators. In the ASMAB II study [13], only $31 \%$ of the patients attending the ED used inhaled corticosteroids regularly. Dominguez-Ortega et al [27] analyzed 83 bronchospasm episodes managed in the ED during a storm in spring: $21 \%$ of the patients had no previous recorded diagnosis of asthma, 93\% had no regular medical visits, and $61.45 \%$ did not receive any treatment for asthma. Serrano-Pariente et al [28] defined 3 different phenotypes of patients who had experienced a near-fatal asthma attack. In cluster 3 in particular, which was characterized by insufficient anti-inflammatory treatment and frequent sensitization to Alternaria alternata and soybean, only $4 \%$ of patients had undergone periodic medical monitoring of their asthma, only $30 \%$ had received inhaled corticosteroids, and none had followed a written action plan for asthma during the attack [28]. Misdiagnosis of asthma has been reported in stable disease, leading to inappropriate treatment and suboptimal patient outcomes [29], and could affect up to $26 \%$ of frequent exacerbators (requiring $\geq 2$ ED visits or hospitalization) [30]. It is also remarkable that more than $40 \%$ of patients were not referred to a specialist on discharge despite having required urgent attention, thus missing an opportunity for collaboration between ED physicians, allergists, and pulmonologists.

Although it has been reported that women [31] and current smokers [32] are at higher risk of asthma exacerbations, surprisingly, we did not find a high associated prevalence in either group in our study. In contrast, older age and previously uncontrolled disease were more prevalent in both groups. We did not analyze these outcomes independently, since older patients are usually at risk for poorer future asthma control [33]. We also found that, in our population, age was associated with a higher rate of hospitalization. Moreover, in the sample studied, $13.7 \%$ of patients had been previously diagnosed with COPD. The prevalence of asthma and COPD overlap syndrome among adults with COPD or asthma ranges from $13 \%$ to $30 \%$, and patients with the syndrome usually have severe disease, with increased rates of exacerbation and hospitalization [34]. Accordingly, we found a frequent association between asthma and comorbid COPD in the population we studied. These results are in agreement with those of a recent Italian multicenter observational study conducted in patients older than 65 years with documented physician-diagnosed asthma. The authors highlighted the negative impact of COPD on asthma control [35]. We also found frequent associations with comorbidities that are also more prevalent among the elderly, such as arterial hypertension, diabetes, and psychiatric disorders. The perception of dyspnea has been reported to decrease with worsening asthma, advancing age, and depression status. Patients with major depression had 3.4-fold higher odds of asthma than those with minimal or no depressive symptoms [36]. Other comorbidities are being explored, with GER, atherosclerosis, hypertension, ischemic heart disease, lipid disorders, and neoplastic disease possibly playing a role, as all have been shown to significantly worsen the degree of asthma control [37]. However, further research is needed to assess whether these comorbidities might influence the risk of exacerbation.

Although no biomarkers accurately predict asthma exacerbations, an elevated eosinophil count in sputum or blood has been associated with a higher risk of asthma exacerbation and hospitalization [12]. Eosinophilic asthma is a common phenotype, and the blood eosinophil count may be useful, as it is easy to assess in clinical practice [38]. However, the issue of whether the blood eosinophil count can confirm an eosinophilic phenotype and the optimal cutoff point for an increased risk of exacerbation remain open to debate. Based on previous recommendations [22], we selected a cutoff of $260 / \mathrm{mm}^{3}$. In addition, $300 / \mathrm{mm}^{3}$ has been reported to be a potential biomarker associated with a successful response to omalizumab [39]. Furthermore, in the PREDUNA study [40] (a retrospective cohort study that examined the relationship between blood eosinophil count at baseline and asthma exacerbations in the following 12 months), a cutoff of $\geq 400 / \mathrm{mm}^{3}$ was strongly associated with future uncontrolled 
asthma (exacerbations and excessive SABA use). However, we found no association between blood eosinophil count and presence of exacerbation. This finding is in agreement with the results of Tran et al [41], who did not find a clear association in a 10-year survey of adults, although they did find a clearer trend toward increased asthma attacks after an additional adjustment for levels of exhaled FeNO and treatment for asthma in the previous 3 months [41]. Moreover, neutrophilic inflammation has been consistently observed in acute asthma associated with viral respiratory tract infections [42], in contrast to noninfective causes of asthma, which are characterized by increased IL-5 and eosinophil activation, thus suggesting differential patterns of inflammation depending on the etiology of the exacerbation. It is interesting that eosinophil levels in children were significantly higher in those who reported more asthma attacks (median blood eosinophil count, 300 cells $/ \mathrm{mm}^{3}$ ), suggesting that higher blood eosinophil counts might play a different role in children with asthma than in adults with the disease. A higher rate of allergic asthma could influence these results. In allergic asthma, inflammation is clearly associated with the presence of eosinophils in the airway and characteristic $\mathrm{T}_{\mathrm{H}} 2$ cytokine expression [43]. As expected, we found allergic asthma to be significantly associated with a higher blood eosinophil cutoff point. Nevertheless, we found a significant inverse association between eosinophil count and risk of admission. This finding differs from those of the pilot study by Hasegawa et al [44], who found that, of 80 patients hospitalized for asthma exacerbation, 32 patients $(40 \%)$ had blood eosinophilia $\left(300 / \mathrm{mm}^{3}\right)$. However, the study was limited by the inclusion of patients with severe acute asthma in the analytic cohort population, which may suggest that their study population was in poorer health than the overall population of patients hospitalized for asthma exacerbation. In our population, the frequency of infection as a cause of exacerbation was exceedingly high, and this may have influenced eosinophil counts [45]. Moreover, the low frequency of hospitalizations due to acute allergic exposure in this population might also have influenced the results, thus decreasing the impact of eosinophilia in the whole population.

In conclusion, asthma exacerbations generate a significant burden for patients with asthma and for the health care system. In this large, population-based study of asthma exacerbations treated at a tertiary hospital over a 1-year period, we found that several factors were relatively common in asthmatics experiencing exacerbation and could be related to the risk of hospitalization. Older age, absence of a previous asthma diagnosis, uncontrolled disease, and concomitant COPD were frequent among patients with exacerbated asthma. These factors were also associated with a higher risk of admission, as were respiratory infections, severity of the exacerbation, and need for intensive treatment in the ED. Blood eosinophil counts should be considered a specific marker of the asthma phenotype, but not as a predictor of hospital admission. Further studies are warranted to better elucidate the role of each specific variable in predicting asthma exacerbations and risk of hospitalization.

\section{Funding}

The authors declare that no funding was received for the present study.

\section{Conflicts of Interest}

The authors declare that they have no conflicts of interest.

\section{References}

1. Demoly P, Paggiaro P, Plaza V, Bolge SC, Kannan H, Sohier $B$, Adamek L. Prevalence of asthma control among adults in France, Germany, Italy, Spain and the UK. Eur Respir Rev. 2009;18:105-12.

2. Custovic A, Johnston SL, Pavord I, Gaga M, Fabbri L, Bel EH Le Souëf $P$, Lötvall J, Demoly $P$, Akdis CA, Ryan D, Mäkelä MJ, Martinez F, Holloway JW, Saglani S, O'Byrne P, Papi A, Sergejeva S, Magnan A, Del Giacco S, Kalayci O, Hamelmann E, Papadopoulos NG.EAACl position statement on asthma exacerbations and severe asthma. Allergy. 2013;68;1520-31.

3. Lozano R, Naghavi M, Foreman K, Lim S, Shibuya K, AboyansV, Abraham J, Adair T, Aggarwal R, Ahn SY, Alvarado M, Anderson HR, Anderson LM, Andrews KG, Atkinson C, Baddour LM, Barker-Collo S, Bartels DH, Bell ML, Benjamin EJ, Bennett D, Bhalla K, Bikbov B, Bin Abdulhak A, Birbeck G, Blyth F, Bolliger I, Boufous S, Bucello C, Burch M, Burney P, Carapetis J, Chen H, Chou D, Chugh SS, Coffeng LE, Colan SD, Colquhoun S, Colson KE, Condon J, Connor MD, Cooper LT, Corriere M, Cortinovis $M$, de Vaccaro KC, Couser W, Cowie BC, Criqui MH, Cross M, Dabhadkar KC, Dahodwala N, De Leo D, Degenhardt L, Delossantos A, Denenberg J, Des Jarlais DC, Dharmaratne SD, Dorsey ER, Driscoll T, Duber H, Ebel B, Erwin PJ, Espindola P, Ezzati $M$, Feigin $V$, Flaxman $A D$, Forouzanfar $M H$, Fowkes FG, Franklin R, Fransen M, Freeman MK, Gabriel SE, Gakidou E, Gaspari F, Gillum RF, Gonzalez-Medina D, Halasa YA, Haring D, Harrison JE, Havmoeller R, Hay RJ, Hoen B, Hotez PJ, Hoy $D$, Jacobsen $K H$, James $S L$, Jasrasaria $R$, Jayaraman $S$, Johns $\mathrm{N}$, Karthikeyan G, Kassebaum N, Keren A, Khoo JP, Knowlton LM, Kobusingye O, Koranteng A, Krishnamurthi R, Lipnick M, Lipshultz SE, Ohno SL, Mabweijano J, Maclntyre MF, Mallinger L, March L, Marks GB, Marks R, Matsumori A, Matzopoulos R, Mayosi BM, McAnulty JH, McDermott MM, McGrath J, Mensah GA, Merriman TR, Michaud C, Miller M, Miller TR, Mock C, Mocumbi AO, Mokdad AA, Moran A, Mulholland K, Nair MN, Naldi L, Narayan KM, Nasseri K, Norman P, O'Donnell M, Omer SB, Ortblad K, Osborne R, Ozgediz D, Pahari B, Pandian JD, Rivero AP, Padilla RP, Perez-Ruiz F, Perico N, Phillips D, Pierce K, Pope CA 3rd, Porrini E, Pourmalek F, Raju M, Ranganathan D, Rehm JT, Rein DB, Remuzzi G, Rivara FP, Roberts T, De León FR, Rosenfeld LC, Rushton L, Sacco RL, Salomon JA, Sampson U, Sanman E, Schwebel DC, Segui-Gomez M, Shepard DS, Singh D, Singleton J, Sliwa K, Smith E, Steer A, Taylor JA, Thomas B, Tleyjeh IM, Towbin JA, Truelsen T, Undurraga EA, Venketasubramanian N, Vijayakumar L, Vos T, Wagner GR, Wang M, Wang W, Watt $K$, Weinstock MA, Weintraub R, Wilkinson JD, Woolf $A D$, Wulf S, Yeh PH, Yip P, Zabetian A, Zheng ZJ, Lopez AD, Murray CJ, AlMazroa MA, Memish ZA. Global and regional mortality from 235 causes of death for 20 age groups in 1990 and 2010: a systematic analysis for the Global Burden of Disease Study 2010. Lancet. 2012;380:2095-128.

4. Jackson DJ, Sykes A, Mallia P, Johnston SL. Asthma exacerbations: Origin, effect and prevention. J Allergy Clin Immunol. 2011;128:1165-74. 
5. Brisk R, Heaney LG. Asthma control and exacerbations: two different sides of the same coin. Curr Opin Pulm Med. 2016;22:32-7

6. Lane S, Molina J, Plusa T. An international observational prospective study to determine the cost of asthma exacerbations: (COAX). Respir Med. 2006;100:434-50.

7. O’Byrne PM, Pedersen S, Lamm CJ, Tan WC, Busse WW. Severe exacerbations and decline in lung function in asthma. Am J Respir Crit Care Med. 2009;179:19-24.

8. Graham LM, Eid N. The impact of asthma exacerbations and preventive strategies. Curr Med Res Opin. 2015;31:825-35.

9. Papadopoulos NG, Christodoulou I, Rohde G, Agache I, Almqvist C, Bruno A,Bonini S, Bont L, Bossios A, Bousquet J, Braido F, Brusselle G, Canonica GW, Carlsen KH, Chanez P, Fokkens WJ, Garcia-Garcia M, Gjomarkaj M, Haahtela T, Holgate ST, Johnston SL, Konstantinou G, Kowalski M, Lewandowska-Polak A, Lødrup-Carlsen K, Mäkelä $M$, Malkusova I, Mullol J, Nieto A, Eller E, Ozdemir C, Panzner P, Popov T, Psarras S, Roumpedaki E, Rukhadze M, StipicMarkovic A, TodoBom A, Toskala E, van Cauwenberge $P$, van Drunen C, Watelet JB, Xatzipsalti M, Xepapadaki P, Zuberbier T. Viruses and bacteria in acute asthma exacerbations: a GA(2) LEN-DARE systematic review. Allergy. 2011;66:458-68.

10. Murphy AC, Proeschal A, Brightling CE, Wardlaw AJ, Pavord I, Bradding P,Green RH. The relationship between clinical outcomes and medication adherence in difficult-to-control asthma. Thorax. 2012:67:751-3.

11. Chlumský J, Striz I, Terl M, Vondracek J. Strategy aimed at reduction of sputum eosinophils decreases exacerbation rate in patients with asthma. J Int Med Res. 2006;34:129-39.

12. Price D, Wilson AM, Chisholm A, Rigazio A, Burden A, Thomas $M$, King C. Predicting frequent asthma exacerbations using blood eosinophil count and other patient data routinely available in clinical practice. J Asthma Allergy. 2016;9:1-12.

13. Morell F, Genover T, Benaque E, Picado C, Muñoz X, Cruz $M J$. Incidence and characteristics of asthma exacerbations in Barcelona (ASMAB II). Arch Bronconeumol. 2009;45:550-5.

14. Linares T, Campos A, Torres M, Reyes J. Medical audit on asthma in an emergency department. Allergol Immunopathol (Madr). 2006;34:248-51.

15. Otero González I, Blanco Aparicio M, Montero Martínez C, Valiño López P, Verea Hernando $H$. The epidemiology of COPD and asthma exacerbations in a general hospital. Arch Bronconeumol. 2002;38:256-62.

16. http://www.madrid.org/cs/Satellite?cid=1142399368017\& language $=$ es $\&$ pagename $=$ HospitalLaPaz $\% 2 \mathrm{FPage} \% 2 \mathrm{FHP}$ AZ_contenidoFinal. Accessed November 23, 2016.

17. https://www.msssi.gob.es/estadEstudios/estadisticas/docs/ CIE9MC_2014_def_accesible.pdf. Accessed November 24, 2016.

18. Tattersfield AE, Postma DS, Barnes PJ, Svensson PJ, Bauer CA, O’Byrne PM, Löfdahl CG, Pauwels RA, Ullman A. Exacerbations of asthma. A descriptive study of 425 severe exacerbations. Am J Respir Crit Care Med. 1999;160;594-99.

19. Nowak RM, Parker JM, Silverman RA, Rowe BH, Smithline $H$, Khan F, Fiening JP, Kim K, Molfino NA.A randomized trial of benralizumab, an antiinterleukin 5 receptor $\alpha$ monoclonal antibody after acute asthma. Am J Emerg Med. 2015;33;1420.
20. Fahy V, Fleming HE, Wong HH, Liu JT, Su JQ, Reimann J, Fick RB Jr, Boushey HA. The effect of an anti-lgE monoclonal antibody on the early- and late-phase responses to allergen inhalation in asthmatic subjects. Am J Respir Crit Care Med. 1997; 155:1828-34.

21. Executive Committee GEMA 2009. GEMA 2009: Spanish guideline on the management of asthma. J Investig Allergol Clin Immunol. 2010;20 Suppl 1:1-59.

22. Zhang $X Y$, Simpson JL, Powell $H$, Yang IA, Upham JW, Reynolds PN, Hodge S, James AL, Jenkins C, Peters MJ, Lin JT, Gibson $P G$. Full blood count parameters for the detection of asthma inflammatory phenotypes. Clin Exp Allergy. 2014;44:1137-45.

23. Quezada W, Kwak ES, Reibman J, Rogers L, Mastronarde J, Teague W, Wei C, Holbrook JT, DiMango E. Predictors of asthma exacerbation among patients with poorly controlled asthma despite inhaled corticosteroid treatment. Ann Allergy Asthma Immunol. 2016;116:112-7.

24. Peters SP, Jones CA, Haselkorn T, Mink DR, Valacer DJ, Weiss ST. Real-world Evaluation of Asthma Control and Treatment (REACT): findings from a national Web-based survey. J Allergy Clin Immunol. 2007;119:1454-61.

25. Chipps BE, Zeiger RS, Dorenbaum A, Borish L, Wenzel S, Miller DP, Hayden ML, Bleecker ER, Simons FE, Szefler SJ, Weiss ST, Haselkorn T. TENOR Study Group. Assessment of asthma control and asthma exacerbations in the epidemiology and natural history of asthma: outcomes and treatment regimens (TENOR) observational cohort. Curr Respir Care Rep. 2012;1:259-69.

26. Rabe KF, Vermeire PA, Soriano JB, Maier WC. Clinical management of asthma in 1999: the Asthma Insights and Reality in Europe (AIRE) study. Eur Respir J. 2000;16:802-7.

27. Domínguez Ortega J, Martín Santos S, Hinojosa Mena-Bernal J, Alonso Llamazares A, Llamas C, Plaza A, Robledo J, MartínezCócera C. Análisis de 83 episodios de broncoespasmo atendidos una noche de primavera en urgencias. Allergol et Immunopathol. 2001;29:197-200.

28. Serrano-Pariente J, Rodrigo G, Fiz JA, Crespo A, Plaza V, High Risk Asthma Research G. Identification and characterization of near-fatal asthma phenotypes by cluster analysis. Allergy. 2015;70:1139-47.

29. Tinkelman DG, Price DB, Nordyke RJ, Halbert RJ. Misdiagnosis of COPD and asthma in Primary Care Patients 40 years of age and over. J Asthma. 2006;43:75-80.

30. Jain VV, Allison DR, Andrews S, Mejia J, Mills PK, Peterson MW. Misdiagnosis among frequent exacerbators of clinically diagnosed asthma and COPD in absence of confirmation of airflow obstruction. Lung. 2015;193:505-12.

31. Patel M, Pilcher J, Reddel HK, Qi V, Mackey B, Tranquilino T, Shaw D, Black P, Weatherall M, Beasley R; SMART Study Group. Predictors of severe exacerbations, poor asthma control and $\beta$-agonist overuse for patients with asthma. J Allergy Clin Immunol Pract. 2014;2:751-8.

32. Thomson NC, Chaudhuri R, Livingston E. Asthma and cigarette smoking. Eur Respir J. 2004;24:822-33.

33. Lombardi C, Raffetti E, Caminati M, Liccardi G, Passalacqua G, Reccardini F, Ridolo E, Senna G, Steinhilber G, Milanese M; onbehalf of the ELSA Study Group. Phenotyping asthma in the elderly: allergic sensitization and upper airways comorbidity in patients older than 65 years. Ann Allergy Asthma Immunol. 2016;116:206-11. 
34. Ding B, Enstone A. Asthma and chronic obstructive pulmonary disease overlap syndrome (ACOS): structured literature review and physician insights. Expert Rev Respir Med. 2016;10:363-71.

35. Milanese M, Di Marco F, Corsico AG, Rolla G, Sposato B, Chieco-Bianchi F, Costantino MT, Crivellaro MA, Guarnieri G, Scichilone N; on behalf of the ELSA Study Group. Asthma control in elderly asthmatics: An Italian observational study. Resp Med. 2014;108:1091-9.

36. Han YY, Forno E, Marsland AL, Miller GE, Celedón JC. Depression, Asthma and Bronchodilator Response in a Nationwide Study of US Adults. J Allergy Clin Immunol Pract. 2016;4:68-73.

37. Panek M, Mokros $\measuredangle$, Pietras T, Kuna P. The epidemiology of asthma and its comorbidities in Poland - Health problems of patients with severe asthma as evidenced in the Province of Lodz. Respir Med. 2016;112:31-8.

38. Fajt ML, Wenzel SE. Asthma phenotypes and the use of biologic medications in asthma and allergic disease: the next steps toward personalized care. J Allergy Clin Immunol. 2015;135:299-310.

39. Busse W, Spector S, Rosén K, Wang Y, Alpan O. High eosinophil count: a potential biomarker for assessing successful omalizumab treatment effects. J Allergy Clin Immunol. 2013;132:485-6.

40. Zeiger RS, Schatz M, Li Q, Chen W, Khatry DB, Gossage D, Tran TN. High blood eosinophil count is a risk factor for future asthma exacerbations in adult persistent asthma. J Allergy Clin Immunol Pract. 2014;2:741-50.

41. Tran TN, Khatry DB, Ke X, Ward C, Gossage D. High blood eosinophil count is associated with more frequent asthma attacks in asthma patients. Ann Allergy Asthma Immunol. 2014;113:19-24.

42. Wark PAB, Johnston SL, Moric I, Simpson JL, Hensley MJ, Gibson PG. Neutrophil degranulation and cell lysis is associated with clinical severity in virus-induced asthma. Eur Resp J. 2002;19:68-75.

43. Mathur SK, Viswanathan RK. Relevance of allergy in adult asthma. Curr Allergy Asthma Rep. 2014;14:437.

44. Hasegawa K, Stoll SJ, Ahn J, Bittner JC. Prevalence of eosinophilia in hospitalized patients with asthma. Respir Med. 2015;109;1230-32.

45. Zhu J, Message SD, Qiu Y, Mallia P, Kebadze T, Contoli M, Ward CK, Barnathan ES, Mascelli MA, Kon OM, Papi A, Stanciu LA, Jeffery PK, Johnston SL. Airway inflammation and illness severity in response to experimental rhinovirus infection in asthma. Chest. 2014;145:1219-29.

Manuscript received October 14, 2016; accepted for publication December 14, 2016.

\section{- Beatriz Pola Bibian}

Allergy Department

Hospital Universitario La Paz

Paseo de la Castellana, 261

28046 Madrid, Spain

E-mail: beatrizpolabibian@gmail.com 